УДК 631.1:314:330(477.44)

(C) 2015

Рідей Н. М., доктор педагогічних наук

Національний університет біоресурсів і природокористування України

Кучеренко Ю. А., аспірант

(науковий керівник - доктор педагогічних наук, професор Н. М. Рідей)

Теліжинська Т. В., здобувач

(науковий керівник - доктор педагогічних наук, професор Н. М. Рідей)

Інститут агроекології і природокористування НААНУ

\title{
ОЦІККА СОЦІО-ЕКОНОМІЧНОГО РОЗВИТКУ СІЛ ІВАНІВКА І ЦВІЖИН ІВАНІВСЬКОЇ СІЛЬСЬКОЇ РАДИ ВІННИЦЬКОГО РАЙОНУ ВІННИЦЬКОЇ ОБЛАСТІ
}

\section{Рецензент - доктор сільськогосподарських наук, професор П. В. Писаренко}

Проведено соиіо-економічне оцінювання базових $і$ атретованих показників - захищеності життєвого рівня, демографічних та інфраструктурних показників, забезпечення людськими і інтелектуальними ресурсами, доходів населення, житлового і транспортного забезпечення та рівня безробіття. Встановлено типи сільських поселень за кількістю мешканців. Визначено індекси за інтегрованими (базовими) та агретованими показниками соціального й економічного розвитку сільських поселень Іванівської сільської ради Вінницького району Вінницької області та встановлено рівень $i$ стан сочіоекономічного розвитку сільських населених пунктів протягом 2012-2014 років.

Ключові слова: сільські населені пункти, рівень сочіо-економічного розвитку сільських населених пунктів, інтегровані та агреговані показники.

Постановка проблеми. Питання комплексного (соціального, економічного, екологічного) оцінювання територій агросфери (сільські території, сільські населені пункти, сільські поселення і т. п.) є недостатньо обгрунтованим у науковій літературі, особливо це стосується діагностики перспектив розвитку сільських територій на основі дослідження їх потенційних можливостей, а саме: соціальних, економічних та екологічних аспектів.

Автори статті питанням комплексного моніторингу присвятили низку наукових публікацій, a саме: загальним питанням дослідження складових агросфери [16], вивченням особливостей та видів потенціалів сільських територій $[17,18]$, а також теоретичним аспектам та науковометодичним підходам до соціо-економікоекологічного моніторингу та їх оцінювання [15].

Аналіз останніх досліджень і публікацій, у яких започатковано розв'язання проблеми.
Оцінюванням та прогнозуванням розвитку територій та демографічним прогнозуванням займаються сучасні науковці: Білинська М., Балдич Н., Берданова О., Гринчук Н. [1]; комплексним демографічним прогнозуванням по Україні на період до 2050 p. та розробкою соціальнодемографічної політики - Власенко Н. та Лібанова Е. [9, 10]; демографічною статистикою Підгорний А. [13]; економічним оцінюванням та прогнозуванням - Білинська М., Шаров Ю., Бобровська О., Латинін М. [2]; прогнозуванням у плануванні економічного і соціального розвитку територій присвячені праці Мамонова В. [11]; проблемні аспекти розвитку українського села висвітлені у наукових роботах Фурдичка О., Палапи Н. та ін. [21]; оцінкою стану агросфери сільських населених пунктів за показниками стійкого розвитку - Клименко Л. [8]; соціальноекономічним розвитком села і сільських територій - Терещенко В., Лайка П. [19]; соціоекономіко-екологічним розвитком району Прищепа А., Клименко Л. [14]; засади сталого розвитку, соціального та соціоекологічного оцінювання сільських населених пунктів, розкрито - Мельником Л., Боголюбим В. [12].

Соціоекономічне оцінювання - методики та методичні рекомендації щодо вимірювання людського розвитку регіонів України (2001); паспортизації сільського населеного пункту (2011); формування економічного механізму екобезпечного сільськогосподарського землекористування (2012); моніторингу і оцінювання програм розвитку малого і середнього підприємства (підхід із залученням зацікавлених сторін) (2013); розрахунку індексу соціоекономіко-екологічного розвитку району (2009).

Мета дослідження - визначення індексів за інтегрованими (базовими) та агрегованими показ- 


\section{EKOHOMIKA}

никами соціального й економічного розвитку сільських поселень Іванівської сільської ради Вінницького району Вінницької області для встановлення рівня і стану соціоекономічного розвитку сільських населених пунктів.

Завдання - соціоекономічне оцінювання базових і агрегованих показників: захищеності життєвого рівня, демографічних та інфраструктурних показників, забезпечення людськими і інтелектуальними ресурсами, доходів населення, житлового і транспортного забезпечення та рівня безробіття; встановлення типів сільських поселень та визначення інтегрованих показників соціоекономічного розвитку СНП Іванівської сільської ради Вінницького району.

Об ' $\epsilon$ - рівень і стан соціоекономічного розвитку сільських населених пунктів.

Предмет - соціоекономічні показники сільських населених пунктів.

Результати досліджень. Вінницький район розташований у центральній частині Вінницької області, яка знаходиться у Південно-Західній частині України в межах Подільської і Придністровської височин. Площа Вінницького району сягає 95,5 тис. га, що становить 3,6 \% від території Вінницької області. Межує з Липовецьким, Немирівським, Тиврівським, Жмеринським, Літинським та Калинівським районами.

Клімат району помірно континентальний. Середня температура повітря найтеплішого місяця - липня $+18-20{ }^{0} \mathrm{C}$, найхолоднішого - січня 4 $6{ }^{0} \mathrm{C}$ морозу. Середні річні суми опадів становлять 590-650 мм. У холодний період року (листопад-березень) випадає 155-205 мм, у теплий період року - 435-445 мм опадів.

Серед спектру різноманітності грунтів регіону виділяємо наступні - чорноземи опідзолені середньо- i важкосуглинкові на лесах, темно-сірі опідзолені важкосуглинкові та сірі-лісові грунти на лесах. Запаси гумусу коливаються від 3,4 до 4,3\% [4].

За густотою населення [20] Вінницького району Вінницької області чітко видно, що густота населення в центрі району висока (101-200 мешканців на 1 м $^{2}$ ), а в південній частині району середня (51-100 мешканців на $1 \mathrm{~m}^{2}$ ).

Рівень міжрегіональної міграції населення у Вінницькому районі сприятливий $(-0,9-(-0,5)$ приріст або скорочення населення на 1000 осіб). Природний рух населення Вінницького району середній $(-8,1-(-9,0)$ осіб на 1000 жителів). Оскільки рівень зайнятості населення Вінницького району еталонний (60,1-70,0 \% до кількості всього населення у віці 15-70 років), то й рівень безробіття сприятливий $(7,1-10,0$ \% до кількості всього населення у віці $15-70$ років).

Забезпеченість населення Вінницького району житловим фондом - еталонного рівня (20013030 м $^{2}$ загальної площі на одну особу).

Економічні збитки від надзвичайних ситуацій природного і техногенного характеру у Вінницькому районі - еталонного рівня $(0-0,10 \%$ до всеукраїнського рівня).

Середня багаторічна екологічна залежність здоров'я населення Вінницького району має сприятливий рівень (16,1-18,0 \% до максимально можливого його рівня). Смертність населення Вінницького району - сприятливого рівня (0,76-1,15, середня кількість померлих 3 усіх причин на 100000 осіб).

Урбанізоване навантаження у Вінницькому районі помірне (41-60 балів), лише в південносхідних областях району слабке (21-40 балів).

Промислова освоєніть Вінницького району Вінницької області високоіндустріалізована. Сільськогосподарська освоєність земель у південно-східній частині Вінницького району сприятлива (76-85 у загальній площі адміністративних районів, \%), а в північно-західній - задовільний (61-75 у загальній площі адміністративних районів, \%).

Соціально-економічна освоєність території Вінницького району по всій території висока (15,1 і більше), а в південній частині району середня (за інтегральними показниками 3,6-7,0). Господарська освоєність земель Вінницького району середня (40-60\% до загальної площі району). Територіальна концентрація виробництва Вінницького району має підвищену оцінку територіальної концентрації (за інтегральними показниками, К.т.к. 10-18).

За рейтинговими місцями індексу людського розвитку (складовими якого є демографічний розвиток, розвиток ринку праці, матеріальний добробут, умови проживання населення, стан та охорона здоров'я, рівень освіти, соціальне середовище, фінансування людського розвитку, екоситуація) Вінницький район Вінницької області посідає 6-те місце в Україні (3 27-ми районів).

Під час проведення оцінки рівня соціоекономічного розвитку сіл Іванівка та Цвіжин Вінницького району Вінницької області протягом 2012-2014 років, використовували методичні рекомендації 3 розрахунку індексу соціоекономіко-екологічного розвитку району (Прищепа А. , Клименко Л. , 2009 р.) [14]. 
ЕКОНОМIKA

1. Типізація сільських поселень за кількістю мешканців (Киричок О., 2002)

\begin{tabular}{|c|c|c|c|c|c|}
\hline $\begin{array}{c}\text { Тип } \\
\text { поселення }\end{array}$ & $\begin{array}{c}\text { Кількість } \\
\text { жителів, чол. }\end{array}$ & $\begin{array}{l}\text { \% від зага- } \\
\text { льної кіль- } \\
\text { кості посе- } \\
\quad \text { лення }\end{array}$ & $\begin{array}{l}\text { \% від загаль- } \\
\text { ної кількості } \\
\text { жителів }\end{array}$ & $\begin{array}{c}\text { Демографічна } \\
\text { ситуація }\end{array}$ & Примітки \\
\hline \multirow{5}{*}{$\begin{array}{c}\text { Малі села } \\
\text { (хутори) }\end{array}$} & До 10 & \multirow{5}{*}{35} & \multirow{5}{*}{6} & Дуже погана & \multirow{5}{*}{$\begin{array}{c}80 \text { \% малих сіл - вими- } \\
\text { раючі села, соціальна } \\
\text { сфера у занепаді }\end{array}$} \\
\hline & $11-25$ & & & Дуже погана & \\
\hline & $26-50$ & & & Дуже погана & \\
\hline & $51-100$ & & & Погана & \\
\hline & $101-200$ & & & $\begin{array}{c}\text { Частково } \\
\text { задовільна }\end{array}$ & \\
\hline Середні села & $200-500$ & 25 & 14 & $\begin{array}{c}\text { Задовільна i } \\
\text { погана }\end{array}$ & $\begin{array}{l}\text { Маятникова міграція } \\
\text { між містом і селом }\end{array}$ \\
\hline \multirow{5}{*}{$\begin{array}{c}\text { Великі } \\
\text { поселення }\end{array}$} & $501-1000$ & \multirow{5}{*}{40} & \multirow{5}{*}{80} & \multirow{4}{*}{$\begin{array}{c}\text { Задовільна i } \\
\text { середня }\end{array}$} & \multirow{4}{*}{$\begin{array}{c}\text { Модельні поселення з } \\
\text { переважанням зайнятос- } \\
\text { ті у агросфері, розвинена } \\
\text { соціальна сфера }\end{array}$} \\
\hline & $1001-2000$ & & & & \\
\hline & 2001-3000 & & & & \\
\hline & $3001-5000$ & & & & \\
\hline & Понад 5000 & & & $\begin{array}{c}\text { Задовільна i } \\
\text { середня }\end{array}$ & $\begin{array}{c}\text { Посилена маятникова } \\
\text { міграція між містом і } \\
\text { селом }\end{array}$ \\
\hline
\end{tabular}

Аналітичне дослідження соціоекономічного розвитку сільських населених пунктів (далі СНП) становить система показників (індикаторів) районної і місцевої статистичної звітності, які об’єднані в агреговані соціальні й економічні показники.

До групи соціальних агрегованих показників входять демографічні, інфраструктурні, захищеності життєвого рівня населення, забезпеченість людськими та інтелектуальними ресурсами. А в групу економічних агрегованих показників включені показник доходів, житлового і транспортного забезпечення, безробіття. Оцінювання соціоекономічного розвитку СНП включало три основні рівні оцінки і агрегування показників: перший - забезпечує оцінку статистичних інформативних базових показників, які характеризують рівень соціоекономічної підсистеми СНП; другий - агреговані показники, які розраховували 3 декількох базових і характеризували стан споріднених групових соціоекономічної підсистеми СНП; третій - інтегровані показники, які розрахували на базі низки агрегованих показників і характеризували стан соціоекономічного розвитку підсистем СНП.

Між показниками (індикаторами) всіх рівнів існує лише вертикально підпорядковані зв'язки.

Переважна більшість індикаторів відноситься до позитивних, тобто їх збільшення покращує соціоекономічний стан СНП, проте є і негативні індикатори, зростання яких кількісно погіршує стан підсистем СНП.

Приведення базових індикаторів різних типів до нормованого виду здійснювали за формулами $(1,2)$ :

$$
\mathrm{X}=\frac{\mathrm{Ni}-\mathrm{N}(\min )}{\mathrm{N}(\max )-\mathrm{N}(\min )} \text { для позитивних індика- }
$$

торів;

$$
\mathrm{X}_{1}=\frac{\mathrm{N}(\max )-\mathrm{N}_{\mathrm{i}}}{\mathrm{N}(\max )-\mathrm{N}(\min )} \text { для негативних інди- }
$$

каторів

Оцінка «0» означає втрату соціальної, економічної значимості індикатора, а оцінка «1» характеризує достатній його розвиток, за яким виникає потреба у громади лише підтримувати досягнутий рівень.

Водночас за максимальні $\mathrm{N}_{(\max )}$ позитивні і мінімальні $\mathrm{N}_{(\min )}$ негативні слід брати значення базових показників, які відповідають кращим у СНП згідно 3 нормативами запропонованими науковцями. Оцінку демографічних показників, які характеризують демографічні та міграційні процеси у СНП здійснювали за шкалою їх типізації (Киричок О., 2002), згідно з якою їх поділяють на наступні поселення: малі села, середні села, великі поселення (табл. 1). 
EKOHOMIKA

2. Визначення індексу інтетрованих показників (за базовими) соціального і економічного розвитку с. Іванівка та с. Цвіжсин Іванівської сільської ради Вінницького району

\begin{tabular}{|c|c|c|c|c|c|c|c|c|c|}
\hline \multirow{2}{*}{$\begin{array}{l}\text { Складо- } \\
\text { ві розви- } \\
\text { тку } \\
\end{array}$} & \multirow[t]{2}{*}{ Показники } & \multicolumn{4}{|c|}{$\begin{array}{c}\text { с. Іванівка: базові показники / } \\
\text { Нормативні значення }\end{array}$} & \multicolumn{4}{|c|}{$\begin{array}{c}\text { с. Цвіжин: базові показники / } \\
\text { Нормативні значення }\end{array}$} \\
\hline & & 2012 & 2013 & 2014 & $\mathrm{n}$ & 2012 & 2013 & 2014 & $\mathrm{n}$ \\
\hline 1 & 2 & 3 & 4 & 5 & 6 & 7 & 8 & 9 & 10 \\
\hline \multirow{3}{*}{$\begin{array}{c}\text { Захи- } \\
\text { щеності } \\
\text { життє- } \\
\text { вого } \\
\text { рівня }\end{array}$} & $\begin{array}{c}\text { Кількість постражда- } \\
\text { лих від аварії, } \\
\text { \% від населення } \\
\end{array}$ & $0 / 5$ & $0 / 5$ & $0 / 5$ & $0 / 5$ & $0 / 5$ & $0 / 5$ & $0 / 5$ & $0 / 5$ \\
\hline & \begin{tabular}{|c|} 
Кількість інвалідів, \\
на 10 тис. населення \\
\end{tabular} & $6 / 5$ & $6 / 5$ & $6 / 5$ & $6 / 5$ & $2 / 5$ & $2 / 5$ & $0 / 5$ & $1,3 / 5$ \\
\hline & $\begin{array}{c}\text { Коефіцієнт злочин- } \\
\text { ності на } 100 \text { тис. } \\
\text { населення } \\
\end{array}$ & $0 / 5$ & $0 / 5$ & $0 / 5$ & $0 / 5$ & $0 / 5$ & $0 / 5$ & $0 / 5$ & $0 / 5$ \\
\hline \multirow{6}{*}{$\begin{array}{l}\text { Демо- } \\
\text { графіч- } \\
\text { ні }\end{array}$} & $\begin{array}{l}\text { Кількість населення, } \\
\text { осіб }\end{array}$ & $594 / 3$ & $604 / 3$ & $590 / 3$ & $596 / 3$ & $178 / 1$ & $182 / 1$ & $178 / 1$ & $179,3 /$ \\
\hline & $\begin{array}{c}\text { Народжуваність, } \\
\text { на } 1000 \text { осіб }\end{array}$ & $3 / 1$ & $5 / 1$ & $5 / 1$ & $4,3 / 1$ & $2 / 1$ & $2 / 1$ & $0 / 1$ & $1,3 / 1$ \\
\hline & $\begin{array}{l}\text { Смертність, } \\
\text { на } 1000 \text { осіб }\end{array}$ & $5 / 5$ & $9 / 5$ & $19 / 3$ & $11 / 4$ & $4 / 5$ & $4 / 5$ & $3 / 5$ & $3,6 / 5$ \\
\hline & $\begin{array}{l}\text { Природний приріст, } \\
\text { на } 1000 \text { осіб }\end{array}$ & $-2 / 1$ & $-4 / 1$ & $-14 / 1$ & $-6,6 / 1$ & $-2 / 1$ & $-2 / 1$ & $-3 / 1$ & $-2,3 / 1$ \\
\hline & $\begin{array}{c}\text { Механічний приріст, } \\
\text { на } 1000 \text { осіб }\end{array}$ & $+21 / 5$ & $+14 / 5$ & $0 / 3$ & $11,6 / 5$ & $-1 / 1$ & $+6 / 5$ & $+3 / 5$ & $+2,6 / 5$ \\
\hline & $\begin{array}{c}\text { Тип вікової структу- } \\
\text { ри, 1-14 років, } \\
\% \text { від населення }\end{array}$ & $18 / 1$ & $20 / 2$ & $20 / 2$ & $19 / 1$ & $14 / 1$ & $18 / 1$ & $29 / 4$ & $20 / 1$ \\
\hline \multirow{8}{*}{$\begin{array}{l}\text { Інфра- } \\
\text { струк- } \\
\text { турні }\end{array}$} & Сільрада & $1 / 2$ & $1 / 2$ & $1 / 2$ & $1 / 2$ & $1 / 2$ & $1 / 2$ & $1 / 2$ & $1 / 2$ \\
\hline & Заклади освіти & $1 / 2$ & $1 / 2$ & $1 / 2$ & $1 / 2$ & $1 / 2$ & $1 / 2$ & $1 / 2$ & $1 / 2$ \\
\hline & $\begin{array}{c}\text { Дитячі дошкільні } \\
\text { заклади } \\
\end{array}$ & $0 / 1$ & $0 / 1$ & $0 / 1$ & $0 / 1$ & $0 / 1$ & $0 / 1$ & $0 / 1$ & $0 / 1$ \\
\hline & Медичні заклади & $1 / 2$ & $1 / 2$ & $1 / 2$ & $1 / 2$ & $1 / 2$ & $1 / 2$ & $1 / 2$ & $1 / 2$ \\
\hline & Торгівельні заклади & $1 / 2$ & $1 / 2$ & $1 / 2$ & $1 / 2$ & $1 / 2$ & $1 / 2$ & $1 / 2$ & $1 / 2$ \\
\hline & \begin{tabular}{|l|} 
Відділення зв'язку \\
\end{tabular} & $1 / 2$ & $1 / 2$ & $1 / 2$ & $1 / 2$ & $1 / 2$ & $1 / 2$ & $1 / 2$ & $1 / 2$ \\
\hline & Підприє & $1 / 2$ & $1 / 2$ & $1 / 2$ & $1 / 2$ & $1 / 2$ & $1 / 2$ & $1 / 2$ & $1 / 2$ \\
\hline & Приватний & $1 / 2$ & $1 / 2$ & $1 / 2$ & $1 / 2$ & $1 / 2$ & $1 / 2$ & $1 / 2$ & $1 / 2$ \\
\hline \multirow{3}{*}{$\begin{array}{c}\text { Забез- } \\
\text { печення } \\
\text { людсь- } \\
\text { кими та } \\
\text { інтелек- } \\
\text { туаль- } \\
\text { ними } \\
\text { ресур- } \\
\text { сами }\end{array}$} & \begin{tabular}{|c} 
Частина працюючого \\
населення, \\
\% від населення \\
\end{tabular} & $55 / 5$ & $51 / 4$ & $58 / 5$ & $54,8 / 5$ & $53 / 4$ & $46 / 3$ & $53 / 4$ & $50,6 / 4$ \\
\hline & \begin{tabular}{|c|} 
Рівень захворювання \\
на туберкульоз на \\
100 тис. населення \\
\end{tabular} & $0 / 5$ & $0 / 5$ & $0 / 5$ & $0 / 5$ & $0 / 5$ & $0 / 5$ & $0 / 5$ & $0 / 5$ \\
\hline & $\begin{array}{l}\text { Чисельність учнів, } \\
\text { \% від населення }\end{array}$ & $11 / 1$ & $13 / 1$ & $13 / 1$ & $12,3 / 1$ & $10 / 1$ & $12 / 1$ & $13 / 1$ & $11,6 / 1$ \\
\hline \multirow{2}{*}{$\begin{array}{c}\text { Доходи } \\
\text { населе- } \\
\text { ння }\end{array}$} & $\begin{array}{c}\text { Доходів місцевого } \\
\text { бюджету, тис. } \\
\text { грн./особу } \\
\end{array}$ & $325 / 1$ & $315 / 1$ & 339 / 1 & $326,3 / 3$ & $325 / 1$ & $315 / 1$ & $339 / 1$ & $326,3 / 3$ \\
\hline & $\begin{array}{l}\text { Індивідуальних } \\
\text { доходів, грн. }\end{array}$ & $1266 / 3$ & $1266 / 3$ & $1266 / 3$ & $1266 / 3$ & $629 / 2$ & $629 / 2$ & $629 / 2$ & $629 / 2$ \\
\hline
\end{tabular}


ЕКОНОМІКА

Продовження таблищі 2

\begin{tabular}{|c|c|c|c|c|c|c|c|c|c|}
\hline 1 & 2 & 3 & 4 & 5 & 6 & 7 & 8 & 9 & 10 \\
\hline \multirow{3}{*}{$\begin{array}{c}\text { Житло- } \\
\text { ве і } \\
\text { транс- } \\
\text { портне } \\
\text { забезпе- } \\
\text { чення }\end{array}$} & $\begin{array}{c}\text { Забезпеченість жит- } \\
\text { лом, м² на особу }\end{array}$ & $19 / 5$ & $19 / 5$ & $20 / 5$ & $19,3 / 5$ & $21 / 5$ & $21 / 5$ & $21 / 5$ & $21 / 5$ \\
\hline & $\begin{array}{c}\text { Транспортне забез- } \\
\text { печення, кількість } \\
\text { маршрутів }\end{array}$ & $6 / 3$ & $6 / 3$ & $6 / 3$ & $6 / 3$ & $5 / 3$ & $5 / 3$ & $5 / 3$ & $5 / 3$ \\
\hline & $\begin{array}{c}\text { Відстань до } \\
\text { райцентру, км }\end{array}$ & $16 / 4$ & $16 / 4$ & $16 / 4$ & $16 / 4$ & $23 / 4$ & $23 / 4$ & $23 / 4$ & $23 / 4$ \\
\hline $\begin{array}{l}\text { Безро- } \\
\text { біття }\end{array}$ & $\begin{array}{c}\text { Наявне безробіття, \% } \\
\text { від працездатного } \\
\text { населення }\end{array}$ & $4 / 4$ & $4 / 4$ & $5 / 4$ & $4,3 / 4$ & $0 / 5$ & $1 / 5$ & $0 / 5$ & $0 / 5$ \\
\hline
\end{tabular}

За статистичними даними Вінницького району [4], с. Іванівка за типом поселення відноситься до маленьких сіл, які нараховують від 101 до 200 осіб, а с. Цвіжин - велике поселення, яке нараховує від 501 до 1000 жителів.

Рівень соціоекономічного розвитку (далі РСЕР) за базовими показниками оцінюється в двоаспектному трактуванні:

шкала I: 1 - дуже низький, 2 - низький, 3 - середній, 4 - високий, 5 - дуже високий;

шкала II: 1 - критичний, 2 - загрозливий, 3 задовільний, 4 - сприятливий, 5 - еталонний.

Вихідні дані РСЕР с. Іванівка та с. Цвіжин Іванівської сільської ради Вінницького району $[3,4,5,6,7]$ представлені в таблиці 2.

Аналізуючи показники захищеності життєвого рівня с. Іванівка та с. Цвіжин за нормативами, можемо зробити висновок про дуже високий (еталонний) РСЕР даних населених пунктів.

За демографічними показниками с. Іванівка має середній (задовільний) РСЕР, а с. Цвіжин має низький (загрозливий) РСЕР.

За інфраструктурою с. Іванівка та с. Цвіжин за соціоекономічними нормативами оцінюються як такі, що мають низький (загрозливий) РСЕР.

Забезпечення людськими та інтелектуальними ресурсами по сукупності блоку показників с. Іванівка має високий (сприятливий), а с. Цвіжин має середній (задовільний) РСЕР.

Доходи даних СНП за сукупністю показників - низького (загрозливого) рівня майбутнього матеріального благополуччя.

За сукупністю блоку показників житлового i транспортного забезпечення с. Іванівка та с. Цвіжин характеризуються як високого (сприятливого) РСЕР.

Показник безробіття вказує на те, що в с. Іванівка має такий відсоток безробітних, які за нормативами діагностики рівня соціоекономіч- ного стану діагностується як сприятливий, а в селі Цвіжин - як еталонний.

Отже, РСЕР с. Іванівка та с. Цвіжин за нормативами в цілому має задовільний (середній) рівень перспективного розвитку.

Після проведення оцінки РСЕР сіл Іванівка та Цвіжин Іванівської сільської ради Вінницького району за 2012-2014 роки встановлено, що СНП мають задовільний (середній) РСЕР.

Комплексне оцінювання стану соціоекономічного розвитку (далі - ССЕР) СНП враховувало підсистеми агрегованих демографічних та соціально-економічних показників: захищеності життєвого рівня населення - кількості постраждалих від катастроф і аварій, кількості інвалідів, коефіцієнта злочинності; демографічної ситуації - кількості населення у СНП народжуваності, смертності, природного приросту, типів вікової структури; інфраструктури - включає дані про наявність на території СНП сільрад, закладів освіти, дитячих дошкільних закладів, медичних і торгівельних закладів, підприємств побуту, станів приватного сектору та рівнях їх електрифікації, газифікації, водозабезпечення та каналізації; забезпеченості людськими і інтелектуальними ресурсами - частки працездатного населення, рівня захворюваності на туберкульоз, чисельності учнів; соціально-економічних - доходів місцевих бюджетів, індивідуальних доходів; життєвого і транспортного забезпечення - забезпеченості населення житлом, транспортного забезпечення, відстані до райцентру; наявного безробіття.

Оцінку ССЕР території СНП виконували шляхом розрахунку нормованих показників у шкалі від 0 до 1 з використанням значень max i min та їх коливань у межах району, або згідно з нормативами [14]. Результати розрахунків представлені в таблиці 3. 
ЕКОНОMIKA

3. Визначення агретованих показників соціоекономічного розвитку

с. Іванівка та с. Цвіжин Іванівськой сільської ради Віннццького району

\begin{tabular}{|c|c|c|c|c|c|c|c|c|c|}
\hline \multirow{2}{*}{$\begin{array}{l}\text { Складові } \\
\text { розвитку }\end{array}$} & \multirow[t]{2}{*}{ Показники } & \multicolumn{3}{|c|}{$\begin{array}{c}\text { с. Іванівка } \\
\mathrm{N}_{\mathrm{i}} / \mathrm{X}_{\mathrm{i}}\end{array}$} & \multicolumn{3}{|c|}{$\begin{array}{l}\text { с. Цвіжин } \\
\mathrm{N}_{\mathrm{i}} / \mathrm{X}_{\mathrm{i}} \\
\end{array}$} & \multicolumn{2}{|c|}{ По району } \\
\hline & & 2012 & 2013 & 2014 & 2012 & 2013 & 2014 & $\max$ & $\min$ \\
\hline 1 & 2 & 3 & 4 & 5 & 6 & 7 & 8 & 9 & 10 \\
\hline \multirow{3}{*}{$\begin{array}{l}\text { Захище- } \\
\text { ності } \\
\text { житте- } \\
\text { вого рівня }\end{array}$} & $\begin{array}{c}\text { Кількість постражда- } \\
\text { лих від аварії, } \\
\text { \% від населення }\end{array}$ & $0 / 1,14$ & $0 / 1,14$ & $0 / 1,14$ & $0 / 1,14$ & $0 / 1,14$ & $0 / 1,14$ & 80 & 10 \\
\hline & $\begin{array}{l}\text { Кількість інвалідів, } \\
\text { на } 10 \text { тис. населення }\end{array}$ & $6 / 1,01$ & $6 / 1,01$ & $6 / 1,01$ & $2 / 1,03$ & $2 / 1,03$ & $0 / 1,14$ & 300 & 10 \\
\hline & $\begin{array}{c}\text { Коефіцієнт злочинності } \\
\text { на } 100 \text { тис. населення }\end{array}$ & $0 / 2,8$ & $0 / 2,8$ & $0 / 2,8$ & $0 / 2,8$ & $0 / 2,8$ & $0 / 2,8$ & 420 & 270 \\
\hline \multicolumn{2}{|c|}{ Агрегований показник } & 1,47 & 1,47 & 1,47 & 1,48 & 1,48 & 1,53 & - & - \\
\hline \multirow{6}{*}{$\begin{array}{l}\text { Демо- } \\
\text { графічні }\end{array}$} & $\begin{array}{c}\text { Кількість населення, } \\
\text { осіб }\end{array}$ & $\begin{array}{l}594 / \\
0,067\end{array}$ & $\begin{array}{l}604 / \\
0,068\end{array}$ & $\begin{array}{l}590 / \\
0,067\end{array}$ & $\begin{array}{c}178 / \\
0,0040\end{array}$ & $\begin{array}{c}182 / \\
0,0042\end{array}$ & $\begin{array}{c}178 / \\
0,0048\end{array}$ & 6780 & 146 \\
\hline & $\begin{array}{l}\text { Народжуваність, } \\
\text { на } 1000 \text { осіб }\end{array}$ & $\begin{array}{c}5,05 / \\
0,16\end{array}$ & $\begin{array}{c}8,23 / \\
0,27\end{array}$ & $\begin{array}{c}8,47 / \\
0,28\end{array}$ & $\begin{array}{c}11,24 / \\
0,37\end{array}$ & $\begin{array}{c}10,98 / \\
0,36\end{array}$ & $\begin{array}{c}5,62 / \\
0,18\end{array}$ & 30 & 0 \\
\hline & $\begin{array}{l}\text { Смертність, } \\
\text { на } 1000 \text { осіб }\end{array}$ & $\begin{array}{l}8,42 / \\
0,820\end{array}$ & $\begin{array}{l}14,9 / \\
0,600\end{array}$ & $\begin{array}{l}32,2 / \\
0,026\end{array}$ & $\begin{array}{c}22,5 / \\
0,35\end{array}$ & $\begin{array}{c}21,97 / \\
0,37\end{array}$ & $\begin{array}{c}16,9 / \\
0,54\end{array}$ & 33 & 3 \\
\hline & $\begin{array}{l}\text { Природний приріст, } \\
\text { на } 1000 \text { осіб }\end{array}$ & $\begin{array}{c}-3,36 / \\
0,6\end{array}$ & $\begin{array}{c}-6,62 / \\
0,5\end{array}$ & \begin{tabular}{|c|}
$-23,73 /$ \\
0,007
\end{tabular} & $\begin{array}{c}-11,23 / \\
0,37\end{array}$ & $\begin{array}{c}-10,98 \\
0,38\end{array}$ & $\begin{array}{c}-16,85 / \\
0,21\end{array}$ & 10 & -24 \\
\hline & $\begin{array}{r}\text { Механічний п } \\
\text { на } 1000 \text { о }\end{array}$ & $\begin{array}{c}+35,3 / \\
0,906\end{array}$ & $\begin{array}{c}+23,2 / \\
0,664\end{array}$ & $\begin{array}{c}+1,69 / \\
0,233\end{array}$ & $\begin{array}{l}-5,6 / \\
0,088\end{array}$ & $\begin{array}{c}+32,9 / \\
0,860\end{array}$ & $\begin{array}{c}+16,8 / \\
0,537\end{array}$ & 40 & -10 \\
\hline & $\begin{array}{c}\text { Тип вікової структури, } \\
1-14 \text { років, } \\
\text { \% від населення } \\
\end{array}$ & $\begin{array}{l}18 / \\
0,21\end{array}$ & $\begin{array}{l}20 / \\
0,29\end{array}$ & $\begin{array}{l}20 / \\
0,29\end{array}$ & $14 / 0,07$ & $18 / 0,21$ & $\begin{array}{l}29 / \\
0,61\end{array}$ & 40 & 12 \\
\hline \multicolumn{2}{|c|}{ Агрегований показник } & 0,317 & 0,317 & 0,077 & 0,103 & 0,185 & 0,179 & - & - \\
\hline \multirow{8}{*}{$\begin{array}{l}\text { Інфра- } \\
\text { струк- } \\
\text { турні }\end{array}$} & Сільрада & $1 / 0,25$ & $1 / 0,25$ & $1 / 0,25$ & $1 / 0,25$ & $1 / 0,25$ & $1 / 0,25$ & 4 & 0 \\
\hline & Заклади освіти & $1 / 0,25$ & $1 / 0,25$ & $1 / 0,25$ & $1 / 0,25$ & $1 / 0,25$ & $1 / 0,25$ & 4 & 0 \\
\hline & $\begin{array}{c}\text { Дитячі дошкільні } \\
\text { заклади } \\
\end{array}$ & $1 / 0,25$ & $1 / 0,25$ & $1 / 0,25$ & $1 / 0,25$ & $1 / 0,25$ & $1 / 0,25$ & 4 & 0 \\
\hline & Медичні заклади & $1 / 0,25$ & $1 / 0,25$ & $1 / 0,25$ & $1 / 0,25$ & $1 / 0,25$ & $1 / 0,25$ & 4 & 0 \\
\hline & Торгівельні заклади & $1 / 0,25$ & $1 / 0,25$ & $1 / 0,25$ & $1 / 0,25$ & $1 / 0,25$ & $1 / 0,25$ & 4 & 0 \\
\hline & Відділення зв'язку & $1 / 0,25$ & $1 / 0,25$ & $1 / 0,25$ & $1 / 0,25$ & $1 / 0,25$ & $1 / 0,25$ & 4 & 0 \\
\hline & Підприємства побуту & $1 / 0,25$ & $1 / 0,25$ & $1 / 0,25$ & $1 / 0,25$ & $1 / 0,25$ & $1 / 0,25$ & & 0 \\
\hline & Приватний сектор & $1 / 0,25$ & $1 / 0,25$ & $1 / 0,25$ & $1 / 0,25$ & $1 / 0,25$ & $1 / 0,25$ & 4 & 0 \\
\hline \multicolumn{2}{|c|}{ Агрегований показник } & 0,25 & 0,25 & 0,25 & 0,25 & 0,25 & 0,25 & - & - \\
\hline \multirow{3}{*}{$\begin{array}{c}\text { Забезпе- } \\
\text { чення } \\
\text { людськи- } \\
\text { ми та інте- } \\
\text { лектуаль- } \\
\text { ними ре- } \\
\text { сурсами }\end{array}$} & \begin{tabular}{|c|} 
Частина працюючого \\
населення, \\
\% від населення \\
\end{tabular} & $\begin{array}{c}54,5 / \\
0,86\end{array}$ & $\begin{array}{l}51 / \\
0,72\end{array}$ & $58 / 1$ & $53 / 0,8$ & $46 / 0,52$ & $53 / 0,8$ & 58 & 33 \\
\hline & $\begin{array}{c}\text { Рівень захворювання } \\
\text { на туберкульоз } \\
\text { на } 100 \text { тис. населення }\end{array}$ & $0 / 1$ & $0 / 1$ & $0 / 1$ & $0 / 1$ & $0 / 1$ & $0 / 1$ & 120 & 0 \\
\hline & $\begin{array}{c}\text { Чисельність учнів, } \\
\text { \% від населення }\end{array}$ & $\begin{array}{c}11,3 / \\
0,06\end{array}$ & $\begin{array}{l}13 / \\
0,15\end{array}$ & $\begin{array}{l}13 / \\
0,15\end{array}$ & $10 / 0$ & $12 / 0,1$ & $\begin{array}{l}13 / \\
0,15\end{array}$ & 30 & 10 \\
\hline \multicolumn{2}{|c|}{ Агрегований показник } & 0,37 & 0,47 & 0,53 & 0 & 0,37 & 0,49 & - & - \\
\hline \multirow{2}{*}{$\begin{array}{c}\text { Доходи } \\
\text { населення }\end{array}$} & $\begin{array}{l}\text { Доходів місцевого бюд- } \\
\text { жету, тис. грн./особу }\end{array}$ & $\begin{array}{c}0,325 / \\
0,019 \\
\end{array}$ & $\begin{array}{c}0,315 / \\
0,017 \\
\end{array}$ & $\begin{array}{c}0,339 / \\
0,018 \\
\end{array}$ & $\begin{array}{c}0,325 / \\
0,017\end{array}$ & $\begin{array}{c}0,315 / \\
0,017\end{array}$ & $\begin{array}{c}0,339 / \\
0,018\end{array}$ & 15 & 0,06 \\
\hline & $\begin{array}{c}\text { Індивідуальних } \\
\text { доходів, грн. }\end{array}$ & $\begin{array}{c}1266 / \\
0,75\end{array}$ & $\begin{array}{c}1266 / \\
0,75\end{array}$ & $\begin{array}{c}1266 / \\
0,75\end{array}$ & $\begin{array}{l}629 / \\
0,45\end{array}$ & $\begin{array}{l}629 / \\
0,45\end{array}$ & $\begin{array}{c}629 / \\
0,45\end{array}$ & 1582 & 316 \\
\hline
\end{tabular}


Продовження таблищі 3

\begin{tabular}{|c|c|c|c|c|c|c|c|c|c|}
\hline 1 & 2 & 3 & 4 & 5 & 6 & 7 & 8 & 9 & 10 \\
\hline \multicolumn{2}{|c|}{ Агрегований показник } & 0,118 & 0,112 & 0,116 & 0,087 & 0,087 & 0,090 & - & - \\
\hline \multirow{3}{*}{$\begin{array}{c}\text { Житлове i } \\
\text { транс- } \\
\text { портне } \\
\text { забезпе- } \\
\text { чення }\end{array}$} & $\begin{array}{c}\text { Забезпеченість } \\
\text { житлом, м² на особу }\end{array}$ & $\begin{array}{l}19 / \\
0,75\end{array}$ & $\begin{array}{l}19 / \\
0,75\end{array}$ & $\begin{array}{l}20 / \\
0,87\end{array}$ & $21 / 1$ & $21 / 1$ & $21 / 1$ & 21 & 13 \\
\hline & $\begin{array}{c}\text { Транспортне } \\
\text { забезпечення, } \\
\text { кількість маршрутів } \\
\end{array}$ & $6 / 0,42$ & $6 / 0,42$ & $6 / 0,42$ & $5 / 0,33$ & $5 / 0,33$ & $5 / 0,33$ & 13 & 1 \\
\hline & $\begin{array}{c}\text { Відстань до райцентру, } \\
\text { км }\end{array}$ & $\begin{array}{l}16 / \\
0,85\end{array}$ & $\begin{array}{l}16 / \\
0,85\end{array}$ & $\begin{array}{l}16 / \\
0,85 \\
\end{array}$ & $23 / 0,76$ & $23 / 0,76$ & $\begin{array}{l}23 / \\
0,76\end{array}$ & 80 & 5 \\
\hline \multicolumn{2}{|c|}{ Агрегований показник } & 0,65 & 0,62 & 0,68 & 0,63 & 0,62 & 0,63 & - & - \\
\hline Безробіття & $\begin{array}{c}\text { Наявне безробіття, } \\
\text { \% від працездатного } \\
\text { населення } \\
\end{array}$ & $4 / 0,8$ & $4 / 0,8$ & $5 / 0,75$ & $0 / 1$ & $1 / 0,95$ & $0 / 1$ & 20 & 0 \\
\hline \multicolumn{2}{|c|}{ Агрегований показник } & 0,80 & 0,80 & 0,75 & 1 & 0,95 & 1 & - & - \\
\hline
\end{tabular}

Для оцінки стану соціальної та економічної підсистем рекомендується використовувати уніфіковану шкалу оцінювання: $1,0-0,8$ - еталонний стан; $0,8-0,6$ - сприятливий; $0,6-0,4$ - задовільний; 0,4 0,2 - загрозливий; $0,2-0$ - критичний.

За результатами розрахунків агрегованих показників, які представлені в таблиці 3 можна оцінити ССЕР СНП протягом 2012-2014 pp.

Захищеність життєвого рівня с. Іванівка та с. Цвіжин за агрегованими показниками свідчить про еталонний ССЕР.

Щодо демографічних агрегованих показників СНП відповідно мають загрозливий, критичний CCEP.

За агрегованими показниками оцінки стану інфраструктури с. Іванівка та с. Цвіжин діагностовано як загрозливий ССЕР.

Забезпечення людськими та інтелектуальними ресурсами по сукупності блоку агрегованих показ- ників вказує на задовільний ССЕР с. Іванівка та загрозливий ССЕР у с. Цвіжин.

Доходи населення у СНП за сукупністю агрегованих показників свідчать про критичний ССЕР. За сукупністю блоку агрегованих показників житлового і транспортного забезпечення ССЕР СНП Іванівка та Цвіжин - сприятливий.

Агреговані показники безробіття вказують на те, що в с. Іванівка ССЕР сприятливий, а в с. Цвіжин еталонний ССЕР.

На підставі агрегованих показників розраховували інтегровані показники соціального та економічного розвитку територій СНП, які представлені в таблиці 4.

За результатами розрахунків інтегрованих показників соціального та економічного розвитку територій сільських поселень Іванівської сільської ради Вінницького району Вінницької області ССЕР с. Іванівка - задовільний, а с. Цвіжин - загрозливий.

\section{4. Розрахунок інтегрованих показників соціального та економічного розвитку територій СНП}

\begin{tabular}{|c|c|c|c|c|c|c|c|c|c|c|}
\hline \multirow[b]{2}{*}{$\begin{array}{c}\text { Назва } \\
\text { сіль- } \\
\text { ської } \\
\text { ради } \\
\text { (СНП) }\end{array}$} & \multirow[b]{2}{*}{ Рік } & \multicolumn{4}{|c|}{ Показники соціального розвитку } & \multirow[b]{2}{*}{$\begin{array}{l}\text { Інтегро- } \\
\text { ваний } \\
\text { показник }\end{array}$} & \multicolumn{3}{|c|}{\begin{tabular}{|c|} 
Показники економічного \\
розвитку
\end{tabular}} & \multirow{2}{*}{$\begin{array}{l}\text { Інтег- } \\
\text { рова- } \\
\text { ний } \\
\text { показ- } \\
\text { ник }\end{array}$} \\
\hline & & $\begin{array}{c}\text { Захищ. } \\
\text { жит. } \\
\text { рівня }\end{array}$ & $\begin{array}{l}\text { Демог- } \\
\text { рафічні }\end{array}$ & $\begin{array}{c}\text { Інфра- } \\
\text { структу- } \\
\text { ра }\end{array}$ & \begin{tabular}{|c|} 
Забезпечен- \\
ня люд- \\
ськими інте- \\
лектуаль- \\
ними \\
ресурсами
\end{tabular} & & $\begin{array}{l}\text { Показ- } \\
\text { ники } \\
\text { доходу }\end{array}$ & $\begin{array}{l}\text { Жит. } \\
\text { трансп. } \\
\text { забезп. }\end{array}$ & $\begin{array}{l}\text { Безро- } \\
\text { біття }\end{array}$ & \\
\hline \multirow{3}{*}{ Іванівка } & 2012 & 1,47 & 0,317 & & 0,37 & 0,455 & 0,118 & 0,65 & 0,80 & 0,394 \\
\hline & 2013 & 1,47 & 0,317 & 0,25 & 0,47 & 0,482 & 0,112 & 0,62 & 0,80 & 0,380 \\
\hline & 2014 & 1,47 & 0,077 & 0,25 & 0,53 & 0,349 & 0,116 & 0,68 & 0,75 & 0,389 \\
\hline \multirow{3}{*}{ Цвіжин } & 2012 & 1,48 & 0,103 & 0,25 & 0 & 0 & 0,087 & 0,63 & 1 & 0,380 \\
\hline & 2013 & 1,48 & 0,185 & 0,25 & 0,37 & 0,397 & 0,087 & 0,62 & 0,95 & 0,371 \\
\hline & 2014 & 1,53 & 0,179 & 0,25 & 0,49 & 0,429 & 0,090 & 0,63 & 1 & 0,383 \\
\hline
\end{tabular}




\section{EKOHOMIKA}

Висновок. Отже, було встановлено, що рівень соціоекономічного розвитку за результатами оцінювання базових показників сільських поселень Іванівської сільської ради Вінницького району Вінницької області - задовільний (середній) (у кожному СНП, окремо і ради, в цілому), а стан соціоекономічного розвитку за агрегованими

\section{БІБЛІОГРАФІЯ}

1. Прогнозування розвитку територій. Демографічне прогнозування : навч. посіб. 3 компактдиском / [Балдич Н. І., Берданова О. В., Гринчук Н. М. та ін.] ; за заг. наук. ред. М. М. Білінської. - К. : НАДУ, 2013. - $120 \mathrm{c}$.

2. Прогнозування розвитку територій. Економічне прогнозування : навч. посіб. 3 компактдиском / [Шаров Ю. П., Бобровська О. Ю., Латинін М. А. та ін.] ; за заг. наук. ред. М. М. Білінської. - К. : К.І.С., 2014. - 128 с.

3. Вінницька обласна рада [Електронний ресурс]. - Режим доступу : http://www.vinrada. gov.ua

4. Вінницька районна державна адміністрація / Паспорт Вінницького району [Електронний ресурс]. - Режим доступу : http://www.vinrda.gov.ua

5. Вінницька районна державна адміністрація / Програма економічного і соціального розвитку Вінницького району за 2014 рік [Електронний pecypc]. - Режим доступу : http://www.vinrda.gov.ua

6. Вінницька районна державна адміністрація / Стратегія розвитку Вінницького району на період до 2020 року [Електронний ресурс]. Режим доступу : http://www.vinrda. gov.ua

7. Вінницька районна рада [Електронний ресурс]. - Режим доступу : http://vinrajrada.org.ua

8. Клименко Л. В. Оцінка стану агросфери сільських населених пунктів за показниками стійкого розвитку : автореф. дис. к. с.-г. н. : спец. 03.00.16 «Екологія» / Л.В.Клименко. - Житомир, 2009. - 20 с.

9. Комплексний демографічний прогноз України на період до 2050 р. / Н. С. Власенко [та ін.] ; ред. Е. М. Лібанова. - Фонд народонаселення ООН, Інститут демографії та соціальних досліджень, Державний комітет статистики України, Український центр соціальних реформ. - К. : [б.в.], 2006. - С. 9.3

10. Лібанова Е. М. Соціально-демографічна політика в Україні у контексті принципів Програми дій МКНР (1994р.) / Лібанова Е. М. // Демографія та соціальна економіка. - 2009. - №2 (12). - С. 12-26.

11. Мамонова $B$. В. Роль прогнозування у плануванні економічного і соціального розвитку територій [Електронний ресурс]. - Режим доступу : file:///C:/Users/pc/Desktop/apdy_2012_1_4.pdf

12. Мельник Л. Г. Устойчивое развитие: тео- показниками, які комплектувалися і розраховувалися у інтегровані, діагностовано як: с. Іванівка - задовільний, а Цвіжин - загрозливий.

Подальші дослідження і публікації будуть присвячені оцінці екологічного розвитку територій сільських поселень Іванівської сільської ради Вінницького району Вінницької області.

рия, методология, практика : учебник / под ред. проф. Л. Г. Мельника. - Сумы : Университетская книга, 2009. - 1216 с.

13. Підгорний А. 3. Курс демографічної статистики : навч. посіб. / А. З. Підгорний. - Одеса : ОДЕУ, 2008. - С. 25-26.

14. Прищепа А. М. Методичні рекомендації 3 розрахунку індексу соціо-економіко-екологічного розвитку району / А. М. Прищепа, Л. В. Клименко. - Рівне : НУВГП, 2009. - 32 с.

15. Науково-методичні підходи до соціоекономіко-екологічного моніторингу агросфери / [Н. М. Рідей, Ю. А. Кучеренко, Д. Л. Шофолов, А. А. Горбатенко] // збірник наукових праць Подільського аграрно-технічного університету. Камянець-Подільський, 2014. - С. 57-60

16. Рідей Н. М. Структурно-функціональна характеристика складових агросфери / Н. М. Рідей, Ю. А. Кучеренко // Вісник Полтавської державної аграрної академії. - Полтава : ПДАА, 2014. №3(74). - С. 36-45.

17. Рідей Н. М. До поняття соціо-економікоекологічного моніторингу сільських територій / Н. М. Рідей, Ю. А. Кучеренко // Таврійський науковий вісник. - Херсон : Грінь Д. С., 2014. B.88. - С. 299-309.

18. Природо-ресурсний потенціал агроекосистем : аналіз понятійно-категоріального апарату, обгрунтування сучасних трактувань / [Рідей Н. М., Горбатенко А. А., Кучеренко Ю. А., Пашутіна О. М.] // Вісник Полтавської державної аграрної академії. - Полтава : ПДАА, 2013. - №3 (70). - С. 13-21.

19. Терещенко B. K. Соціально-економічний розвиток села і сільських територій [текст] : наукововиробниче видання ; за ред. В. К. Терещенка, П. А. Лайка. - К. : [б. в.], 2006. - 264 с.

20. Україна. Еколого-географічний атлас. Атласмонографія. - К. : Варта,2006. - 220 с.

21. Проблемні аспекти розвитку українського села / [Палапа Н. В., Цибро Ю. А., Скрипник Г. Л. та ін.] // Наукові основи сталого розвитку агроекосистем України. Науково-методичні основи збалансованого природокористування в агропромисловому виробництві ; за ред. О. І. Фурдичка. К. : ДІА, 2012. - С. 144-156. 